\author{
STEFAN STOJALOWSKI ${ }^{1}$ \\ MARTA ORLOWSKA ${ }^{1}$ \\ MARTYNA SOBCZYK ${ }^{1}$ \\ ANNA BIENIAS ${ }^{1}$ \\ BEATA MYŚKÓW ${ }^{1}$ \\ PRZEMYSLAW TOMCZAK ${ }^{2}$ \\ WOJCIECH WESOLOWSKI ${ }^{3}$ \\ MAREK SZKLARCZYK ${ }^{3}$ \\ WALDEMAR BRUKWIŃSKI ${ }^{4}$ \\ KATARZYNA BANASZAK ${ }^{4}$ \\ MONIKA HANEK ${ }^{4}$ \\ RENATA KRYSZTROFIK ${ }^{4}$ \\ MAREK ZAJĄC ${ }^{5}$ \\ ${ }^{1}$ Katedra Genetyki, Hodowli i Biotechnologii Roślin, Zachodniopomorski Uniwersytet Technologiczny \\ w Szczecinie \\ ${ }^{2}$ Hala Wegetacyjna, Zachodniopomorski Uniwersytet Technologiczny w Szczecinie \\ ${ }^{3}$ Zakład Genetyki, Hodowli Roślin i Nasiennictwa, Uniwersytet Rolniczy w Krakowie \\ ${ }^{4}$ DANKO Hodowla Roślin Sp. z o.o. \\ ${ }^{5}$ Poznańska Hodowla Roślin Sp. z o.o. \\ Kierownik Tematu: dr hab. Stefan Stojałowski prof. ZUT Katedra Genetyki, Hodowli i Biotechnologii \\ Roślin, Zachodniopomorski Uniwersytet Technologiczny w Szczecinie, Słowackiego 17, 71-434 Szczecin, \\ tel. 91 4496404, e-mail: stefan.stojalowski@zut.edu.pl
}

Prace zostały wykonane w ramach badań podstawowych na rzecz postępu biologicznego w produkcji roślinnej na podstawie decyzji Ministra Rolnictwa $i$ Rozwoju Wsi nr HOR.hn.802.13.2018, Zadanie 20.

\title{
Poszukiwanie wspólnych mechanizmów dziedziczenia płodności roślin z cytoplazmą CMS-C oraz z cytoplazmą CMS-Pampa
}

\section{Search of common genetic mechanisms determining fertility of plants with cytoplasm CMS-C and CMS-Pampa}

Słowa kluczowe: cytoplazmatyczna męska sterylność, odmiany mieszańcowe, żyto

Zjawisko cytoplazmatycznej męskiej sterylności wykorzystywane jest w komercyjnej hodowli odmian mieszańcowych wielu gatunków roślin uprawnych. U żyta znanych jest 
szereg źródeł cytoplazm sterylizujących, ale w praktycznej hodowli dominuje wykorzystanie odkrytej przez Geigera i Schnella (1970) cytoplazmy Pampa (CMS-P). Źródło CMS-C odkryto w Szczecinie (Łapiński, 1972) i obecnie jest ono zaliczane do grupy cytoplazm o nazwie Vavilovii (CMS-V). Realizację badań podjęto z zamiarem bliższego poznania podobieństw i różnic w genetycznej determinacji męskiej sterylności u żyta z cytoplazmą Pampa i cytoplazmą C.

Cele pracy to:

- poszukiwanie markerów związanych z genami przywracania płodności w cytoplazmach C i P na drodze mapowania sprzężeniowego oraz asocjacyjnego,

— walidacja wyników bioinformatycznej analizy danych dotyczących sekwencji DNA mitochondrialnego z cytoplazm: normalnej, Pampa i CMS-C,

— określenie frekwencji roślin męskopłodnych i męskosterylnych w mieszańcach między źródłami CMS-C i CMS-P a populacjami żyta,

- ocena zdolności kombinacyjnej wybranych linii męskosterylnych z cytoplazmą $\mathrm{C}$ na tle linii zawierających cytoplazmę Pampa.

Wyniki mapowania genetycznego w obrębie mieszańców międzyliniowych oraz odmian mieszańcowych wskazują na duże znaczenie genów zlokalizowanych na długim ramieniu chromosomu 4R. Geny zlokalizowane w tym obszarze genomu żyta są istotne w kontrolowaniu męskiej płodności zarówno w cytoplazmie Pampa, jak i C. Wynik ten jest zgodny $\mathrm{z}$ wcześniejszymi doniesieniami literaturowymi (Miedaner i in., 2000; Stracke i in,. 2003; Stojałowski i in., 2004; 2011; Hackauf i in., 2012). Dodatkowe geny o niewielkich efektach fenotypowych zlokalizowane są na kilku różnych chromosomach, a ich rozmieszczenie nie jest identyczne dla obu badanych cytoplazm. Przy ocenie męskiej płodności pojedynczych roślin odmian mieszańcowych, zaobserwowano, że w odmianie Skaltio i Konto udział roślin pylących był bardzo niewielki, więcej męskopłodnych roślin było w odmianie Tur, Stach i Picasso, a najwięcej w odmianie Bono. We wszystkich tych odmianach udział roślin męskosterylnych był jednak nie mniejszy niż 40\%.

Poszukiwania mitochondrialnych czynników genetycznych wywołujących męską sterylność w cytoplazmach Pampa i C nie zakończyły się sukcesem. Zidentyfikowano kilka polimorfizmów mtDNA, ale nie miały one związku z determinacją zjawiska CMS.

Badania nad frekwencją alleli sterylności/płodności wykonano poprzez ocenę płodności mieszańców między źródłami CMS-C i CMS-P a europejskimi populacjami żyta. Ocena płodności była wykonywana wzrokowo przez cały okres kwitnienia żyta, przy zastosowaniu skali bonitacyjnej opracowanej przez Geigera i Morgensterna (1975). Badano trzy historyczne odmiany: z Rosji, Węgier i byłej Jugosławii oraz trzy populacje hodowlane z Polski. Większość badanych populacji bardzo dobrze przywracała płodność w systemie CMS-C, a słabo w CMS-P. Wyjątkiem była jugosłowiańska populacja Landsorte K9538, która charakteryzowała się relatywnie dużą częstotliwością występowania genotypów dopełniających względem cytoplazmy C (prawie 40\%).

Ocenę zdolności kombinacyjnej 30 linii męskosterylnych z cytoplazmami C (4 linie) i P (26 linii) wykonywano $\mathrm{w}$ doświadczeniach polowych trójpowtórzeniowych założonych w dwóch miejscowościach (Wiatrowo i Nagradowice) metodą losowanych 
bloków. Obiektami badawczymi w doświadczeniach były mieszańce wyżej wymienionych linii męskosterylnych $\mathrm{z}$ populacją syntetyczną SR27. Wielkość poletek doświadczalnych do zbioru wynosiła $5 \mathrm{~m}^{2}$. Wykonano ocenę wielkości plonu, wylegania przed zbiorem, porażenia przez rdzę brunatną i wysokości roślin. Poza badanymi 30 mieszańcami eksperymentalnymi w doświadczeniu badano dwie odmiany wzorcowe: KWS Serafino $F_{1}$ i KWS Binnto $F_{1}$. Wszystkie badane $w_{2} 2018$ roku linie dawały mieszańce plonujące wyraźnie gorzej niż odmiany wzorcowe. Plony mieszańców eksperymentalnych stanowiły od nieco ponad $60 \%$ do niespełna $85 \%$ średniego plonu wzorców. Mieszańce eksperymentalne z udziałem trzech linii męskosterylnych z cytoplazmą C należały do najsłabiej plonujących — poniżej $70 \%$ wzorców. Podobny poziom plonowania odnotowano dla ośmiu mieszańców eksperymentalnych z cytoplazmą Pampa. Najlepszy wynik dała linia ZUT_160086P — ponad 75\% plonu wzorca. Pod względem pozostałych badanych $\mathrm{w}$ doświadczeniu cech użytkowych mieszańce $\mathrm{z}$ cytoplazmą $\mathrm{C}$ ocenione zostały na poziomie zbliżonym do tych, w których formy mateczne zawierały cytoplazmę Pampa.

\section{WNIOSKI Z BADAŃ}

1. Odmiany mieszańcowe żyta są wewnętrznie zróżnicowane pod względem przywrócenia męskiej płodności.

2. Geny kontrolujące przywracanie płodności u żyta $z$ cytoplazmami Pampa i $\mathrm{C}$ są zlokalizowane na różnych chromosomach, a największe znaczenie mają geny $\mathrm{z}$ długiego ramienia chromosomu 4R.

3. We wszystkich ocenionych populacjach żyta z Polski i innych krajów Europy przeważały genotypy przywracające męską płodność w systemie CMS-C, a utrzymujące męską sterylność w systemie CMS-P.

4. Badane linie męskosterylne $\mathrm{z}$ cytoplazmami $\mathrm{C}$ i $\mathrm{P}$ dawały mieszańce plonujące słabiej niż zarejestrowane odmiany wzorcowe.

5. Pod względem wysokości, wylegania i porażenia przez rdzę brunatną genotypy z CMS-C nie różniły się od tych z cytoplazmą Pampa.

\section{LITERATURA}

Geiger H. H., Morgenstern K. 1975. Angewandt-genetische Studien zur cytoplasmatischen Pollensterilität bei Winterroggen. Theor. Appl. Genet. 46: $269-276$.

Geiger H. H., Schnell F. W. 1970. Cytoplasmic male sterility in rye (Secale cereale L.). Crop Sci. 10: 590 593.

Hackauf B., Korzun V., Wortmann H., Wilde P., Wehling P. 2012. Development of conserved ortholog set markers linked to the restorer gene Rfp1 in rye. Mol. Breeding 30: 1507 - 1518.

Łapiński M. 1972. Cytoplasmic-genic type of male sterility in Secale montanum Guss. Wheat Inform. Serv. 35: $25-28$

Miedaner T., Glass C., Dreyer F., Wilde P., Wortmann H., Geiger H. H. 2000. Mapping of genes for malefertility restoration in 'Pampa' CMS winter rye (Secale cereale L.). Theor. Appl. Genet. 101: 1226 1233.

Stojałowski S., Łapiński M., Masojć P. 2004. RAPD markers linked with restorer genes for the C-source of cytoplasmic male sterility in rye (Secale cereale L.). Plant Breeding 123: 428 - 433. 
Stojałowski S., Milczarski P., Hanek M., Bolibok-Brągoszewska H., Myśków B., Kilian A., RakoczyTrojanowska M. 2011. DArT markers tightly linked with the Rfc1 gene controlling restoration of male fertility in the CMS-C system in cultivated rye (Secale cereale L.). J. Appl. Genet. 52: $313-318$.

Stracke, S., Schilling, A.G., Forster, J., Weiss, C., Glass, C., Miedaner, T., Geiger, H.H. 2003. Development of PCR-based markers linked to dominant genes for male-fertility restoration in Pampa CMS of rye (Secale cereale L.). Theor. Appl. Genet., 106: 1184 - 1190. 